\title{
KUALITAS TES SUMATIF MATA PELAJARAN MATEMATIKA KELAS VIII SMP NEGERI 5 KENDARI TAHUN AJARAN 2016/2017
}

\author{
Yusdiana $^{1}$, Zamsir $^{2}$, Kodirun $^{3}$ \\ ${ }^{1)}$ Alumni Jurusan Pendidikan Matematika, ${ }^{2,3)}$ Dosen Jurusan Pendidikan Matematika \\ FKIP Universitas Halu Oleo email : yusdiana13@gmail.com;zamsir@uho.ac.id; \\ kodirunzuhry@gmail.com
}

\begin{abstract}
Abstrak
Penelitian ini bertujuan untuk mengetahui: (1) Tingkat kesukaran setiap butir soal, (2) Daya pembeda setiap butir soal, (3) efektifitas pengecoh (distractor), (4) Validitas setiap butir soal, (5) seberapa besar reliabilitas soal , (6) seberapa besar kesalahan baku pengukuran. Berdasarkan hasil analisis data diperoleh kesimpulan :(1) Tingkat kesukaran soal pilihan ganda dan soal uraian belum dinyatakan baik, (2) Daya pembeda soal pilihan ganda dan uraian dinyatatakan berdaya pembeda baik, (3) Keefektifan pengecoh (distractor) soal pilihan ganda dan uraian dinyatakan sebagai efektif, (4) Validitas tes sumatif soal pilihan ganda dan uraian dinyatakan bervaliditas baik, (5) Besarnya indeks reliabilitas soal pilihan ganda sebesar 0,515 dinyatakan kategori sedang. Sedangkan reliabilitas soal uraian sebesar 0,713 dinyatakan kategori tinggi, (6) Besarnya indeks kesalahan baku pengukuran soal pilihan ganda sebesar 1,957. Sedangkan kesalahan baku pengukuran soal uraian sebesar 8,763. Berdasarkan indikator dari tingkat kesukaran, daya pembeda, pengecoh, validitas, reliabilitas tes sumatif dinyatakan belum berkualitas.
\end{abstract}

Kata Kunci : Kualitas tes, tes sumatif, indeks reliabilitas

\section{QUALITY OF SUMATIVE TEACHING MATH CLASS VIII SMP NEGERI 5 KENDARI TEACHING DATE 2016/2017}

\begin{abstract}
This research aims to know the: (1) the level of difficulty of each grain of matter, (2) the power of distinction every grain of matter, (3) the effectiveness of pengecoh (distractor), (4) the validity of any grain of matter, (5) how big a reliability problem, (6) how big errors raw measurements. Based on the results of the analysis of data obtained conclusions:(I) multiple choice question difficulty and problem descriptions have not declared good, (2) multiple choice question the differentiating Power and exposé dinyatatakan helpless good differentiator, (3) the effectiveness of pengecoh (distractor) reserved multiple choice and descriptions are expressed as effective, (4) the validity of the test multiple choice question summative and descriptions stated good bervaliditas, (5) the magnitude of the multiple choice question reliability index of 0.515 stated categories. While the reliability problem descriptions of 0.713 stated high category, (6) the magnitude of the error index of raw measurements of multiple choice question of 1.957. While the raw error measurement of reserved descriptions of 8.763. Based on the indicators of the difficulty level, the power of distinction, pengecoh, validity, reliability, the test has not been stated quality summative.
\end{abstract}

Keywords : quality test, sumative test, reliability index 


\section{Pendahuluan}

Pendidikan dipandang sebagai faktor utama dalam bidang pembangunan, pandangan ini mengandung suatu pengertian bahwa pendidikan dapat memotori dan menopang proses pembangunan (Aliati dan Ibrahim, 2013: 1). Pendidikan juga memiliki kontribusi besar dalam mempersiapkan manusia yang berkualitas dan mengarahkan siswa untuk memahami perannya sebagai manusia yang bertanggung jawab untuk melanjutkan dan meningkatkan pembangunan. Peningkatan kualitas pendidikan adalah salah satu aspek pembangunan yang memegang peranan penting dalam suatu usaha untuk mencapai pembangunan secara menyeluruh. Salah satu faktor penyebab dalam pelaksanaan sistem pendidikan adalah evaluasi belajar atau pencapaian hasil belajar siswa. Keberadaan evaluasi belajar sangat diperlukan dalam kegiatan belajar mengajar berlangsung karena terdapat proses pembelajaran, penilaian, dan evaluasi. Evaluasi merupakan proses yang sangat penting dalam suatu kegiatan yang dilakukan guru untuk mengetahui keberhasilan peserta didik dalam mencapai pembelajaran yang telah dipelajari sebelumnya. Pelaksanaan evaluasi sangat erat kaitannya dengan guru, dimana dalam proses belajar mengajar salah satu peran guru adalah sebagai evaluator dalam memantau keberhasilan siswa.

Guru sebagai evaluator harus memperhatikan persyaratan-persyaratan evaluasi agar memperoleh hasil yang diharapkan dalam upaya mengukur tingkat penguasaan masingmasing siswa pada materi yang telah diajarkan. Dalam melakukan evaluasi, guru memberikan tes sesuai dengan materi yang telah diajarkan. Oleh karena itu, perlu diciptakan alat ukur untuk mengetahui keberhasilan siswa, alat ukur itulah yang sering disebut dengan tes (tes buatan guru). Tes buatan guru memiliki peran penting dalam proses pembelajaran. Dalam pembuatan soal, guru diharuskan untuk menyusun secara baik supaya mempunyai kualitas tes yang baik, sesuai dengan kurikulum dan sesuai dengan materi yang telah diajarkan. Kualitas tes buatan guru dapat mempengaruhi kualitas pembelajaran dan sekaligus kualitas hasil belajar siswa. Tes sumatif dilakukan setelah di akhir suatu pelajaran atau akhir semester dimaksudkan untuk mengukur apa yang telah dipelajari peserta didik setelah suatu keseluruhan pembelajaran. Hasil tes ini digunakan untuk banyak hal antara lain: untuk pemberian nilai siswa, evaluasi efektifitas kurikulum,menilai pencapaian akademik siswa, sekolah, ataupun daerah secara umum selama tahun akademik berjalan (Liliasari, 2015: 39).

Yusuf (2015: 19) menyatakan bahwa evaluasi merupakan suatu proses pengumpulan dan analisa data secara sistematis untuk mengetahui bukti penguasaan peserta didik dalam belajar, ketercapaian tujuan yang telah ditetapkan dan menentukan keefektifan pendidikan atau pembelajaran. Menurut Arifin (2012: 6-7) tes pada hakikatnya adalah suatu alat yang berisi serangkaian tugas yang harus dikerjakan atau soal-soal yang harus dijawab oleh peserta didik untuk mengukur suatu aspek prilaku tertentu. Artinya, tes tersebut adalah sebagai alat ukur. Tes subjektif yang pada umumnya berbentuk essay (uraian). Tes bentuk essay adalah sejenis tes kemajuan belajar yang memerlukan jawaban yang bersifat pembahasan atau uraian kata-kata (Arikunto, 2016: 177). Tes objektif yang juga dikenal dengan istilah jawaban pendek, adalah salah satu jenis tes hasil belajar yang terdiri dari butir-butir soal (item) yang dijawab oleh testee dengan jalan memilih salah satu diantara beberapa kemungkinan jawaban yang telah dipasangkan pada masingmasing item, atau dengan jalan menuliskan jawabannya berupa kata-kata atau simbolsimbol tertentu pada tempat atau ruang yang telah disediakan untuk masing-masing butir item yang bersangkutan (Sudijono, 2015: 106-107).

Pendidikan merupakan faktor yang paling besar peranannya dalam menentukan maju mundurnya pelaksanaan pembangunan bangsa dalam segala bidang. Para ahli pendidikan Indonesia telah berusaha memajukan pendidikan dengan mengadakan penyempurnaan materi pelajaran serta perbaikan sistem pendidikan. Kemajuan suatu lembaga pendidikan dapat dilihat dari hasil keberhasilan lembaga tersebut dalam mengubah tingkah laku anak didik sesuai dengan tujuan yang telah ditetapkan. Dalam mewujudkan hal tersebut, maka pemerintah mendirikan lembaga-lembaga pendidikan mulai pendidikan dasar sampai lembaga pendidikan tinggi. Melalui lembaga pendidikan manusia Indonesia dapat dibina untuk menghasilkan manusia yang berkualitas. Tentunya yang dimaksud disini adalah para peserta didik yang mendapatkan pendidikan di suatu lembaga pendidikan tersebut, dimana 
pada saat mendapatkan pendidikan akan ada proses pembelajaran yang akan diberikan oleh guru (Suryawati dan Yulfikar, 2012: 71-72).

Proses untuk menuju suatu tujuan atau suatu keberhasilan yang telah ditetapkan sangat dipengaruhi oleh beberapa faktor, antara lain faktor guru terhadap peserta didik dalam proses belajar mengajar dikelas, anak didik yang mempunyai karakteristik berbeda-beda, minat anak didik terhadap suatu pelajaran, kegiatan pembelajaran, strategi penggunaan metode pembelajaran, fasilitas yang tersedia, suasana evaluasi serta alat evaluasi dan bahan evaluasi yang baik sehingga peserta didik mendapatkan hasil belajar yang baik maupun kurang baik.

Tes buatan guru sangat berperan penting dalam proses evaluasi hasil belajar siswa, sehingga dibutuhkan suatu tes yang baik yaitu tes yang mampu mengukur apa yang hendak diukur. Suatu gambaran tinggi rendahnya hasil belajar yang diperoleh dengan menggunakan tes yang tidak baik tentu bukan merupakan gambaran yang sebenarnya dari prestasi hasil belajar siswa. Hasil belajar ini akan memberikan informasi yang keliru mengenai pencapaian hasil belajar siswa. Oleh karena itu, salah satu faktor yang mesti dibenahi adalah meningkatkan kualitas tes terhadap butir-butir soal yang dipergunakan dalam evaluasi. Hasil dari tes tersebut digunakan untuk mengukur kemampuan seseorang setelah mengalami proses pembelajaran. Apabila keadaan tes setelah diberikan menunjukkan hampir semua siswa memperoleh skor jelek berarti bahwa tes tersebut mungkin terlalu sukar, sebaliknya jika seluruh siswa memperoleh skor baik berarti tes tersebut terlalu mudah.

Evaluasi merupakan proses yang sangat penting dalam kegiatan pendidikan formal. Bagi guru evaluasi dapat menentukan efektivitas kinerjanya selama ini, sedangkan bagi pengembang kurikulum evaluasi dapat memberikan informasi untuk perbaikan kurikulum yang sedang berjalan. Evaluasi sering dianggap sebagai salah satu hal yang menakutkan bagi siswa Wina sanjaya (2008 : 243-244). Berdasarkan pelaksanaan, prinsip umum evaluasi itu sendiri tidak mengenal adanya perbedaan, kecuali jika kita mencoba meninjau dari segi alat yang digunakan. Dalam hal ini alat evalusi dapat dibedakan menjadi dua macam (Asra dan Sumiati dalam Aliati, 2013: 3 ), yaitu evaluasi menggunakan tes baku dan evaluasi menggunakan tes tidak baku. Tes adalah suatu teknik maupun cara yang digunakan dalam rangka melaksanakan kegiatan pengukuran, yang didalamnya terdapat beberapa pernyataan, pertanyaan, maupun serangkaian tugas yang harus dikerjakan oleh siswa untuk mengukur aspek perilaku siswa Arifin (2009: 118).

Arikunto (2016: 5) menyatakan bahwa tes sumatif adalah tes yang dilakukan oleh guru setelah berakhirnya suatu program yang lebih besar. Dalam pengalaman di sekolah, tes sumatif yang biasanya digunakan seperti ulangan umum yang dilakukan pada saat akhir semester. Selanjutnya Jihad dan Haris ( 2012: 57) mengemukakan bahwa fungsi tes sumatif dalam pelaksanaan hasil belajar adalah biasanya dilakukan pada akhir semester atau akhir tahun ajaran. Sudijono (2015: 67) menyatakan bahwa ada dua macam fungsi yang dimiliki oleh tes yaitu sebagai alat pengukur terhadap peserta didik. Dalam hubungan ini tes berfungsi mengukur tingkat perkembangan atau kemajuan yang telah dicapai oleh peserta didik setelah mereka menempuh proses belajar mengajar dalam jangka waktu tertentu dan sebagai alat pengukur keberhasilan program pengajaran, sebab melalui tes tersebut akan dapat diketahui sudah beberapa jauh program pengajaran yang telah ditentukan, telah dapat dicapai.

Arikunto (2016: 207) mengemukakan bahwa untuk mengidentifikasi soal-soal yang baik, kurang baik dan soal yang jelek dengan analisis soal. Terdapat beberapa hal yang berhubungan dengan analisa soal yaitu taraf kesukaran, daya beda dan pola jawaban soal". Lebih jauh lagi Arikunto menemukakan bahwa "ada beberapa cara melakukan analisis butir soal yaitu analisis tingkat kesukaran, analisis daya beda dan analisis fungsi pengecoh (distractor)". Selain dengan menganalisa soal, tes yang disusun juga harus memenuhi syarat atau ciriciri kualitas tes yang baik. Arikunto (2016: 57) mengemukakan bahwa sebuah tes yang dapat dikatakan baik sebagai alat pengukur harus memenuhi persyaratan tes, yaitu memiliki Validitas, Reliabilitas, Objektivitas, praktikabilitas dan Ekonomis.

Tes adalah sehimpunan soal yang harus dijawab atau direaksi oleh orang yang diuji dengan tujuan untuk mengukur suatu aspek perilaku dari orang tersebut. Soal tes dapat terdiri dari berbagai macam bentuk. Thorndike Hangen mengkategorikan soal kedalam dua bagian, yaitu : 1) soal yang menghendaki peserta 
didik untuk menghasilkan jawaban dengan katakata sendiri, dan 2) soal yang menghendaki peserta didik memilih salah satu dari beberapa alternatif jawaban yang diberikan. Berikut ini di kemukakan beberapa komponen yang berkaitan dengan kebutuhan untuk menganalisis butir soal, yaitu:tingkat kesukaran, daya beda dan pengecoh.

Tingkat kesukaran (difficulty index) dapat didefinisikan sebagai proporsi peserta didik peserta tes yang menjawab benar. Soal yang baik adalah soal yang tidak terlalu mudah atau tidak terlalu sukar. Soal yang terlalu mudah tidak merangsang peserta didik untuk mempertinggi usaha memecahkannya. Sebaliknya soal yang terlalu sukar akan menyebabkan peserta didik menjadi putus asa dan tidak mempunyai semangat untuk mencoba lagi karena di luar jangkauannya Arikunto (2016: 207). Sejalan dengan itu Aliati (2013: 24) menyatakan bahwa tingkat kesukaran suatu butir soal didefenisikan sebagai proporsi atau presentase subjek yang menjawab butir tertentu dengan benar. Sedangkan angka yang menujukkan sukar atau mudahnya suatu butir soal dinamakan indeks kesukaran, yang dilambangkan dengan $\mathrm{p}$, nilai $\mathrm{p}$ ini terletak antara 0 dan 1 .

Berdasarkan pendapat para ahli dapat disimpulkan bahwa tingkat kesukaran tes adalah salah satu ciri tes yang perlu diperhatikan, karena tingkat kesukaran tes menunjukan seberapa sukar atau mudahnya butir-butir tes atau tes secara keseluruhan yang telah diselenggarakan.

Perbandingan proporsi antara soal yang mudah, sedang dan sukar misalnya bisa dibuat 3-4-3. Ini berarti 30\% soal kategori mudah. $40 \%$ soal kategori sedang dan 30\% soal kategori sukar. Perbandingan lain misalnya, 3-5-2. Ini berarti tes tersebut terdiri dari $30 \%$ soal dengan kategori mudah, 50\% kategori sedang dan sisanya $20 \%$ termasuk dalam kategori sukar (Erlina A, 2012: 28).

Liliasari (2015: 40) menyatakan bahwa kriteria tingkat kesukaran yang digunakan dalam penelitian ini adalah sebagai berikut.

$0,00-0,30$ soal kategori sukar,

$0,31-0,70$ soal kategori sedang dan

$0,71-1,00$ soal kategori mudah.

Daya pembeda soal adalah kemampuan suatu butir soal yang dapat membedakan antara peserta didik yang telah menguasai materi yang ditanyakan dan peserta didik yang belum menguasai materi yang ditanyakan.

Analisis daya pembeda butir-butir soal dengan tujuan untuk mengetahui kesanggupan soal dalam membedakan siswa yang tergolong mampu (tinggi prestasinya) dengan siswa yang tergolong kurang atau lemah prestasinya. Tes dikatakan tidak mempunyai daya pembeda apabila tes tersebut diujikan kepada siswa yang tergolong berkemampuan rendah hasilnya lebih tinggi tetapi jika diujikan kepada siswa yang tergolong kemampuan rendah hasilnya lebih tinggi tetapi jika diujikan kepada siswa yang berkemampuan tinggi hasilnya rendah, atau bila diberikan kepada kedua golongan siswa tersebut hasilnya sama. Dengan demikian tes yang tidak memiliki daya pembeda akan menghasilkan gambaran hasil yang sesuai dengan kemampuan siswa yang sebenarnya.

Menurut Djanuarsih (2016: 10) Indeks daya pembeda setiap butir soal biasanya juga dinyatakan dalam bentuk proporsi. Semakin tinggi indeks daya pembeda soal berarti semakin mampu soal yang bersangkutan membedakan warga belajar/siswa yang telah memahami materi dengan warga belajar/peserta didik yang belum memahami materi. Indeks daya pembeda berkisar antara -1,00 sampai dengan $+1,00$. Semakin tinggi daya pembeda suatu soal, maka semakin kuat/baik soal itu. Jika daya pembeda negatif $(<0)$ berarti lebih banyak kelompok bawah (warga belajar/peserta didik yang tidak memahami materi) menjawab benar soal dibanding dengan kelompok atas (warga belajar/peserta didik yang memahami materi yang diajarkan guru) (http: //www.freewebs.com/santyasa/PDF_Files/ANA LISIS_BUTIR.pdf.).

Menurut Arifin (2009: 89) perhitungan daya pembeda adalah pengukuran sejauh mana suatu butir soal dapat membedakan peserta didik yang sudah menguasai kompetensi dengan peserta didik yang belum menguasai kompetensi. Daya Pembeda dapat diketahui dengan melihat besar kecilnya indeks diskriminasi soal. Adapun klasifikasi indeks diskriminasi (daya pembeda) menurut Arikunto (2016: 232) adalah sebagai berikut :
D : $0,00-0,20$ : jelek
D : 0,21-0,40 : cukup
D : $0,41-0,70$ : baik
D : $0,71-1,00$ : baik sekali 
D : negatif, semuanya tidak baik (jelek sekali). Jadi semua butir soal yang mempunyai nilai D negatif sebaiknya dibuang saja.

Berbeda dengan soal bentuk uraian, pada soal pilihan ganda telah dilengkapi beberapa pilihan jawaban. Di antara pilihan jawaban yang ada, hanya satu yang benar. Selain jawaban yang benar tersebut, adalah jawaban yang salah. Jawaban yang salah itulah yang di kenal dengan pengecoh (distractor ). Butir soal yang baik, pengecohnya akan dipilih secara merata oleh peserta didik yang menjawab salah. Sebaliknya, butir soal yang kurang baik, pengecohnya akan dipilih secara tidak merata oleh peserta didik.

Sudijono (2015: 411), mengungkapkan bahwa distractor telah dapat menjalankan fungsinya dengan baik apabila distractor tersebut telah di pilih sekurang-kurangnya $5 \%$ dari seluruh peserta tes. Distractor yang telah menjalankan fungsinya dengan baik dapat digunakan kembali pada tes yang akan dating. Dengan demikian, efektivitas distractor adalah seberapa baik pilihan yang salah tersebut dapat mengecoh peserta tes yang memang tidak mengetahui kunci jawaban yang tersedia. Semakin banyak peserta tes yang memilih distractor tersebut, maka distractor itu dapat menjalankan fungsinya dengan baik. Jika peserta tes mengabaikan semjua option (tidak memilih) disebut omit. Dilihat dari segi omit, sebuah item dikatakan baik jika omitnya tidak lebih dari $10 \%$ pengikut tes.

\section{Validitas Tes}

Suryabrata (2000: 41) menyatakan bahwa validitas tes pada dasarnya menunjuk kepada derajat fungsi pengukurnya suatu tes, atau derajat kecermatan ukurnya sesuatu tes. Validitas suatu tes mempermasalahkan apakah tes tersebut benar-benar mengukur apa yang hendak diukur. Maksudnya adalah seberapa jauh suatu tes mampu mengungkapkan dengan tepat ciri atau keadaan yang sesungguhnya dari obyek ukur, akan tergantung dari tingkat validitas tes yang bersangkutan.

Arikunto (2016: 89) menyatakan bahwa koefisien korelasi selalu terdapat antara $-1,00$ sampai $+1,00$. Koefisien negative menunjukan hubungan kebalikan sedangkan koefisien positif menunjukan adanya kesejajaran untuk mengadakan interprestasi mengenai besarnya koefisien korelasi adalah sebagai berikut: $0,80 \leq r_{x y}<1,00$ sangat tinggi
$0,60 \leq r_{x y}<0,80$ tinggi

$0,40 \leq r_{x y}<0,60$ cukup

$0,20 \leq r_{x y}<0,40$ rendah

$0,00 \leq r_{x y}<0,20$ sangat rendah

Penafsiran harga koefisien korelasi ada dua cara, yaitu:

a. Dengan melihat harga $r$ ( $r$ hitung) dan diterpretasikan misalnya korelasi tinggi, cukup, dan sebagainya.

b. Dengan berkonsultasi ke ( $\mathrm{r}$ tabel) tabel harga kritik $r$ product moment sehingga dapat diketahui valid tidaknya korelasi tersebut. Jika harga $r_{\text {hit }}$ ( $r$ hitung) lebih kecil dar $\mathrm{r}_{\text {tab }}$ ( $\mathrm{r}$ tabel), maka korelasi tersebut invalid. Begitu juga arti sebaliknya.

\section{Reabilitas Tes}

Menurut Sudjana (2006: 6), reliabilitas alat penilaian adalah ketetapan atau keajegan alat tersebut dalam menilai apa yang dinilainya. Artinya, kapan pun alat penilaian tersebut digunakan akan memberikan hasil yang relatif sama. Hal senada juga diungkapkan Chabib (2003: 118), "reliabilitas sering diartikan dengan keterandalan". Artinya, suatu tes memiliki keterandalan jika tes tersebut dipakai mengukur berulang-ulang hasilnya sama. Dengan demikian reliabilitas dapat pula diartikan dengan keajegan atau stabilitas.

Arikunto (2016: 121) menyatakan bahwa kriteria yang digunakan untuk menafsirkan reabilitas tes diklasifikasikan sebagai berikut:

$$
\begin{array}{lr}
0,00-0,20 & \text { reliabilitas } \\
\text { sangat rendah } & \\
0,21-0,40 & \text { rendah } \\
\text { rendah } & \\
0,41-0,69 & \text { sedang } \\
0,61-0,89 & \text { reliabilitas } \\
\text { tinggi } & \\
0,90-1,00 & \text { reliabilitas } \\
\text { sangat tinggi } &
\end{array}
$$

\section{Kesalahan Baku Pengukuran}

Setiap hasil pengukuran terdapat penyimpanan dari skala angka sebenarnya. Penyimpanan ini dapat bernilai positif apabila lebih besar dari skor sebenarnya dan dapat pula bernilai negatif jika lebih kecil dari skor yang sebenarnya. Secara kelompok dapat mengestimasi penyimpanan skor-skor tersebut dengan melihat banyaknya variasi penyimpanan ini. Keslahan baku pengukuran pada umumnya dapat juga menenjukan tingkat reabilitas tes. Jika nilai kesalahan baku pengukuran suatu tes 
yang telah dilakukan kecil, berarti reliabilitas tes tersebut tinggi. Sebaliknya, jika nilai kesalahan baku pengukuran besar, berarti bahwa tes yang dibuat mempunyai reliabilitas rendah Aliati (2013: 21).

\section{Analisis dengan Komputer}

Item and Test Analysis (ITEMAN) merupakan perangkat lunak (software) yang dibuat melalui bahasa pemograman computer yang diciptakan khusus untuk analisis statistikbutir soal dan tes. Program ini dibuat dengan pendekatan analisis statistic secara klasikal yang berguna untuk menentukan kualitas butir soal dan tes berdasarkan data empiris hasil uji coba. Hasil dari analisis soal mencakup informasi mengenai tingkat kesukaran, daya pembeda, efektifitas pengecoh (distraktor) dan statistic sebaran jawaban. Selain menghasilkan statistic butir soal. ITEMAN juga menghaisilkan statistic tes yang meliputi keandalan atau reliabilitas tes, kesalahan pengukuran dan distribusi skor. Program ini juga memberikan output skor untuk setiap pesereta tes.Seluruh data yang akan dianalisis sebagai input dalam analisis berada dalam satu file dengan kapasitas 3,000 responden Aliati (2013: 21).

\section{Metode}

Jenis penelitian yang digunakan adalah penelitian kuantitatif yang menggunakan jenis penelitian deskriptif. Penelitian ini menggunakan evaluasi sumatif untuk mengukur kualitas tes ulangan semester genap kelas VIII mata pelajaran matematika SMP Negeri 5 Kendari Tahun Ajaran 2016/2017. Penelitian ini telah dilaksanakan di SMP Negeri 5 Kendari, dengan waktu pelaksanaannya pada semester genap tahun ajaran 2016/2017.

Teknik pengumpulan data dalam penelitian ini adalah menggunakan data dokumentasi yakni mengambil soal ulangan semester genap dan lembar jawaban peserta tes mata pelajaran matematika tahun ajaran 2016/2017. Tes yang terkumpul kemudian dianalisis secara kuantitatif setiap soal jawaban ulangan semester berdasarkan kunci jawaban.

Teknik analisis data yang akan digunakan dalam penelitian ini yaitu dengan menggunakan program iteman dan cara manual.

1. Cara Manual

a. Tingkat Kesukaran

Amalia dan Widayati (2012: 8) mengatakan bahwa untuk tes bentuk objektif dalam menghitungtu tingkat kesukaran dapat dilakukan dengan menggunakan rumus sebagai berikut:

Keterangan :

$$
P=\frac{B}{J S}
$$

$\mathrm{P}=$ Indeks Kesukaran

dengan bena

$\mathrm{B}=$ Banyaknya siswa yang menjawab

JS = Jumlah peserta tes

Untuk menghitung tingkat kesukaran tes bentuk uraian menurut Amalia dan Widayati (2012 : 8) langkah-langkah yang dilakukan sebagai berikut:

a. Menghitung rata-rata skor untuk tiap butir soal dengan rumus:

$$
\begin{aligned}
& \text { Rata }- \text { rata } \\
& =\frac{\text { Jumlah skor peserta didik tiap soal }}{\text { Jumlah peserta didik }}
\end{aligned}
$$

b. Menghitung tingkat kesukaran dengan rumus:

Tingkat kesukaran

$$
=\frac{\text { rata }- \text { rata }}{\text { skor maksimum tiap soal }}
$$

c. Membandingkan tingkat kesukaran dengan kriteria tingkat kesukaran.

d. Membuat penafsiran tingkat kesukaran dengan cara membandingkan koefisien tingkat kesukaran dengan kriterianya.

\section{b. Daya Pembeda}

Arikunto (2016 : 9) menyatakan bahwa Tes bentuk objektif dalam menghitung daya pembeda dapat dilakukan dengan menggunakan rumus sebagai berikut:

Keterangan :

$$
D=\frac{B_{A}}{J_{A}}-\frac{B_{B}}{J_{B}}
$$

$$
\begin{aligned}
& \mathrm{B}_{\mathrm{A}}= \text { Banyaknya peserta kelompok } \\
& \text { atas yang menjawab soal itu } \\
& \text { dengan benar } \\
& \mathrm{B}_{\mathrm{B}}= \begin{array}{l}
\text { Banyaknya peserta kelompok } \\
\text { bawah yang menjawab soal itu } \\
\text { dengan benar }
\end{array} \\
& \mathrm{J}_{\mathrm{A}}=\text { Banyaknya peserta kelompok atas } \\
& \mathrm{J}_{\mathrm{B}}=\text { Banyaknya peserta kelompok } \\
& \text { bawah }
\end{aligned}
$$

Untuk soal bentuk uraian, teknik yang digunakan untuk menghitung daya pembeda yaitu:

$$
D P=\frac{\bar{X} K A-\bar{X} K B}{\text { Skor Maks }}
$$


Keterangan:

$$
\begin{aligned}
& \mathrm{DP}=\text { Daya pembeda } \\
& \bar{X} \mathrm{KA}=\text { Rata-rata dari kelompok }
\end{aligned}
$$

bawah

$$
\text { Skor Maks }=\text { skor maksimum }
$$

$$
\text { (Arifin, 2009: 9) }
$$

\section{c. Efektifitas Pengecoh (Distractor)}

Sebuah pengecoh (distractor) dapat dikatakan berfungsi dengan baik apabila distractor tersebut mempunyai daya tarik yang besar bagi peserta tes yang kurang memahami konsep atau kurang menguasai bahan. Suatu distractor dapat dikatakan berfungsi dengan baik jika paling sedikit dipilih oleh $5 \%$ pengikut tes Amalia dan Widayati (2012: 13).

d. Validitas Tes

enurut Amalia dan Widayati (2012: 11) menyatakan bahwa untuk tes objektif dalam menentukan uji validitas item dapat dilakukan dengan menggunakan rumus $\gamma_{p b i}$ sebagai berikut:

$$
y_{p b i}=\frac{M p-M t}{S t} \sqrt{\frac{p}{q}}
$$

Keterangan:

$\gamma_{p b i}=$ koefisien korelasi biserial

$\mathrm{Mp}=$ rata-rata skor subjek yang menjawab betul bagi item yang dicari validitasnya

$\mathrm{Mt}=$ rata-rata skor total

$\mathrm{St}=$ standar deviasi dari skor total digunakan :

Untuk tes bentuk uraian rumus yang

$$
r_{x y}=\frac{N \cdot \sum X \cdot Y-\left(\sum X\right)\left(\sum Y\right)}{\sqrt{\left(N \cdot \sum X^{2}-(X)^{2}\right) \cdot\left(N \cdot \sum Y^{2}-\left(\sum Y\right)^{2}\right)}}
$$

Keterangan :

$\mathrm{r}_{\mathrm{xy}}=$ Koefisien korelasi product moment

$\mathrm{N}$ = Banyaknya peserta tes

$\mathrm{X}=$ Skor tiap butir soal siswa pada seluruh butir soal

$\mathrm{Y}=$ Skor total siswa pada seluruh butir soal

(Jihad, 2013 : 180)

e. Reliabilitas Tes

Menurut Yusuf (2015: 81) untuk mencari reliabilitas tes bentuk objektif dapat dilakukan dengan menggunakan rumus:

$$
r 11=\left(\frac{n}{n-1}\right)\left(\frac{s^{2}-\sum p q}{s^{2}}\right)
$$

Keterangan:

keseluruhan

$r 11=$ reliabilitas tes secara

menjawab soal dengan benar

$=$ proporsi subjek yang

$\mathrm{q}=$ proporsi subjek yang menjawab soal dengan salah $(q=1-p)$

$\sum p q=$ jumlah hasil perkalian anatara $\mathrm{p}$ dan $\mathrm{q}$

$\mathrm{n} \quad$ = banyaknya soal

$\mathrm{S} \quad=$ standar deviasi dari tes

Berbeda dengan soal bentuk uraian, untuk soal bentuk uraian dalam mencari reabilitas tes dapat dilakukan dengan menggunakan rumus alpha, yaitu:

$$
r 11=\left(\frac{n}{n-1}\right)\left(1-\frac{\sum a_{i}^{2}}{a_{t}^{2}}\right)
$$

Keterangan:

$r 11=$ reliabilitas tes secara keseluruhan

$$
\begin{array}{ll}
\sum a_{i}^{2} & =\text { jumlah varians skor tiap soal } \\
a_{t}^{2} & =\text { varians total }
\end{array}
$$

banyaknya soal

\section{f. Kesalahan Baku}

Menurut Safari (2005: 33) menyatakan bahwa untuk mengetahui kesalahan baku pengukuran (KBP) digunakan rumus sebagai berikut :

Keterangan :

$$
K B P=S D_{t} \sqrt{1-r_{11}}
$$

$\mathrm{KBP}=$ kesalahan baku pengukuran

$S D_{t}=$ standar deviasi skor tes

$\mathrm{r}_{11}=$ koefisien reliabilitas tes,

\section{Program Iteman}

Teknik analisis data yang akan digunakan dalam penelitian ini yaitu dengan menggunakan program iteman. Data hasil penelitian ini akan dianalisis dengan menggunakan computer yaitu program iteman versi 3,00 untuk menganalisis butir soal pilihan ganda.

\section{Hasil}

Berdasarkan analisis menggunakan Program iteman dalam soal pilihan ganda, 
tingkat kesukaran soal ditunjukan oleh prop correct, daya pembeda soal ditunjukkan oleh biser, pengecoh ditunjukan oleh prop endorsing, validitas ditunjukan oleh point biser, reabilitas tes ditunjukan oleh Alpha, kesalahan baku pengukuran ditunjukan oleh SEM. Sedangkan dalam soal uraian tingkat kesukaran, daya pembeda, validitas, reliabilitas, dan kesalahan baku pengukuran dikerjakan dengan menggunakan rumus. Hasil penelitian dan analisis selengkapnya disajikan berikut :
1. Tingkat Kesukaran
a. Soal pilihan ganda

Tabel 1.

Analisis Tingkat Kesukaran Soal Tes Sumatif Mata Pelajaran Matematika kelas VIII SMP Negeri 5 Kendari Tahun Ajaran 2016/2017.

\begin{tabular}{|c|c|c|c|c|}
\hline No & Kategori Soal & Nomor Butir Soal & Jumlah & $\begin{array}{c}\text { Persentase } \\
\quad(\%)\end{array}$ \\
\hline 1 & Sukar & $5,6,8,9,18$, dan 19 & 6 & 30 \\
\hline 2 & Sedang & $\begin{array}{c}1,3,7,10,11,12,13,14 \\
, 15,16, \text { dan } 17\end{array}$ & 11 & 55 \\
\hline 3 & Mudah & 2,4, dan 20 & 3 & 15 \\
\hline & Jumlah & 20 & 20 & 100 \\
\hline
\end{tabular}

Berdasarkan tabel di atas menunjukan bahwa terdapat 3 butir soal $(15 \%)$ termasuk kategori mudah yakni butir soal nomor 2,4 , dan 20,11 butir soal (55\%) termasuk kategori sedang yakni butir soal nomor $1,3,7,10,11,12,13,14,15$, 16,dan 17, dan 6 butir soal (30\%) termasuk kategori sukar yakni butir soal nomor 5, 6, 8, 9, 18, dan 19 . Proporsi tingkat kesukarannya adalah $3: 11: 6$.

b. Soal Uraian

Tabel 2.

Analisis Tingkat Kesukaran Soal Tes Sumatif Mata Pelajaran Matematika Kelas VIII SMP Negeri 5 Kendari Tahun Ajaran 2016/2017.

\begin{tabular}{|c|c|c|c|c|}
\hline No & $\begin{array}{l}\text { Kategori } \\
\text { Soal }\end{array}$ & Nomor Butir Soal & Jumlah & Persentase (\%) \\
\hline 1 & Sukar & 3 dan 5 & 2 & 40 \\
\hline 2 & Sedang & 1,2, dan 4 & 3 & 60 \\
\hline 3 & Mudah & 0 & 0 & 0 \\
\hline \multicolumn{3}{|c|}{ Jumlah } & 5 & 100 \\
\hline
\end{tabular}

4, dan 2 butir soal (40\%) termasuk kategori

Berdasarkan tabel di atas menunjukan bahwa terdapat 0 butir soal $(0 \%)$ termasuk kategori mudah, 3 butir soal $(60 \%)$ termasuk kategori sedang yakni butir soal nomor 1,2 , dan mudah yakni butir soal nomor 3 dan 4. Proporsi tingkat kesukarannya adalah $1: 2: 2$.

2. Daya Pembeda

a. Soal Pilihan Ganda 
Tabel 3.

Analisis Daya Pembeda Soal Tes Sumatif Mata Pelajaran Matematika kelas VIII SMP Negeri 5 Kendari Tahun Ajaran 2016/2017.

\begin{tabular}{|l|l|c|c|c|}
\hline No & $\begin{array}{c}\text { Kategori } \\
\text { Soal }\end{array}$ & No Item & Jumlah & $\begin{array}{c}\text { Persentase } \\
(\%)\end{array}$ \\
\hline 1 & Jelek & 20 & 1 & 5 \\
\hline 2 & Cukup & $\begin{array}{c}1,3,4,5,7,8,9,10,14 \text { dan } \\
18\end{array}$ & 10 & 50 \\
\hline 3 & Baik & $\begin{array}{c}2,6,11,12,13,15,16,17, \\
\text { dan } 19\end{array}$ & 9 & 45 \\
\hline 4 & Baik Sekali & 0 & 0 & 0 \\
\hline \multicolumn{2}{|r|}{ Jumlah } & 20 & 100 \\
\hline
\end{tabular}

Berdasarkan tabel di atas menunjukan bahwa terdapat 1 butir soal (5\%) mempunyai daya pembeda jelek, 10 butir soal (50\%) mempunyai daya pembeda cukup, 9 butir soal (45\%) mempunyai daya pembeda baik, dan 0 butir soal $(0 \%)$ mempunyai daya pembeda baik sekali.

b. Soal Uraian

Tabel 4.

Analisis Daya Pembeda Soal Tes Sumatif Mata Pelajaran Matematika kelas VIII SMP Negeri 5 Kendari Tahun Ajaran 2016/2017.

\begin{tabular}{|l|l|c|c|c|}
\hline No & Kategori Soal & No Item & Jumlah & $\begin{array}{c}\text { Persentase } \\
(\%)\end{array}$ \\
\hline 1 & Jelek & 0 & 0 & 0 \\
\hline 2 & Cukup & 0 & 0 & 0 \\
\hline 3 & Baik & 3,5 & 2 & 40 \\
\hline 4 & Baik Sekali & $1,2,4$ & 3 & 60 \\
\hline \multicolumn{2}{|c}{ Jumlah } & 5 & 5 & 100 \\
\hline
\end{tabular}

Berdasarkan tabel di atas menunjukan bahwa terdapat 0 butir soal (0\%) mempunyai daya pembeda jelek, 0 butir soal $(0 \%)$ mempunyai daya pembeda cukup, 2 butir soal $(40 \%)$ mempunyai daya pembeda baik yakni butir soal

Tabel 5.

Analisis Pengecoh Butir Soal Tes Sumatif Mata Pelajaran Matematika Kelas VIII SMP Negeri 5 Kendari Tahun Ajaran 2016/2017.

\begin{tabular}{|c|c|c|c|}
\hline Kategori & Nomor Butir Soal & Jumlah & $\begin{array}{c}\text { Presentase } \\
(\%)\end{array}$ \\
\hline Berfungsi & $\begin{array}{c}1,3,5,6,7,8,9,10,11,12,13,14,15,16,17, \\
18, \text { dan } 19\end{array}$ & 17 & 85 \\
\hline $\begin{array}{c}\text { Tidak } \\
\text { berfungsi }\end{array}$ & 2,4, dan 20 & 3 & 15 \\
\hline \multicolumn{2}{|c|}{ Jumlah } & 20 & 100 \\
\hline
\end{tabular}

Berdasarkan tabel di atas menunjukan bahwa terdapat 17 butir soal $(85 \%)$ pengecohnya yang berfungsi yakni butir soal no $1,3,5,6,7,8,9$, $10,11,12,13,14,15,16,17,18,19$ dan 3 butir

soal $(15 \%)$ pengecohnya yang tidak berfungsi yakni butir soal 2, 4, dan 20.

4. Validitas Tes

a. Soal Pilihan Ganda nomor 3 dan 5 , dan 3 butir soal $(60 \%)$ mempunyai daya pembeda baik sekali yakni butir soal nomor 1, 2, dan 3 .

3. Pengecoh (Distractor) 
Tabel 7.

Analisis Validitas Tes Sumatif Mata Pelajaran Matematika kelas VIII SMP Negeri 5 Kendari Tahun Ajaran 2016/2017.

\begin{tabular}{|c|c|c|c|c|}
\hline No & Kategori & No Item & Jumlah & $\begin{array}{l}\text { Presentasi } \\
(\%)\end{array}$ \\
\hline 1 & Valid & $\begin{array}{c}1,2,3,4,5,6,7,9,10,1 \\
1,12,13,14,15,16,17 \\
, 18,19\end{array}$ & 18 & 90 \\
\hline 2 & Tidak Valid & 20 dan 8 & 2 & 10 \\
\hline \multicolumn{3}{|c|}{ Jumlah } & 20 & 100 \\
\hline
\end{tabular}

Berdasarkan tabel di atas menunjukan bahwa terdapat 2 butir soal (10\%) yang yang dikatakan invalid dan 18 butir soal $(90 \%)$ dikatakan valid yakni. Hal ini disesuaikan dengan melihat $r$ tabel sebesar 0,159 .

b. Soal Uraian

Tabel 8.

Analisis Validitas Tes Sumatif Mata Pelajaran Matematika kelas VIII SMP Negeri 5 Kendari Tahun Ajaran 2016/2017.

\begin{tabular}{|c|c|c|c|c|}
\hline No & Kategori & No Item & Jumlah & $\begin{array}{c}\text { Presentasi } \\
(\%)\end{array}$ \\
\hline 1 & Valid & $1,2,3,4,5$ & 5 & 100 \\
\hline 2 & Tidak Valid & 0 & 0 & 0 \\
\hline \multicolumn{2}{|c|}{ Jumlah } & 5 & 5 & 100 \\
\hline
\end{tabular}

Berdasarkan tabel di atas menunjukan bahwa terdapat 0 butir soal $(0 \%)$ yang dikatakan invalid dan 5 butir soal $(100 \%)$ dikatakan valid. Hal ini disesuaikan dengan melihat $\mathrm{r}$ tabel sebesar 0,159 .

\section{Reliabilitas Tes}

a. Soal Pilihan Ganda

Berdasarkan hasil analisis dengan menggunakan program iteman versi 3,00 ditunjukan oleh alpha pada skala statistic (scale statistics). Besarnya reliabilitas tes suamatif mata pelajaran matematika semestrer genap kelas VIII SMP Negeri 5 Kendari tahun ajaran 2016/2017 diperoleh reliabilitas tes sebesar 0,515. Hal ini menunjukan bahwa, soal tersebut memiliki nilai alpha yang tergolong sedang.

b. Soal Uraian

Berdasarkan hasil analisis dengan menggunakan rumus besarnya niliai reliabilitas pada tes sumatif mata pelajaran matematika semester genap kelas VIII SMP Negeri 5 Kendari tahun ajaran 2016/2017 diperoleh nilai sebesar 0,713 . Hal ini menunjukan bahwa soal tersebut tergolong tinggi.

\section{Kesalahan Baku Pengukuran}

a. Soal Pilihan Ganda

Berdasarkan hasil analisis dengan menggunakan program iteman versi 3.00, kesalahan baku pengukuran dapat diketahui dari Standart Error of Measurement (SEM ). Besarnya nilai kesalahan baku pengukuran pada tes suamatif mata pelajaran matematika semester genap kelas VIII SMP Negeri 5 Kendari tahun ajaran 2016/2017 diperoleh nilai SEM sebesar 1,957 .

b. Soal Uraian

Berdasarkan hasil analisis dengan menggunakan rumus besarnya nilai kesalahan baku pengukuran tes sumatif mata pelajaran matematika siswa kelas VIII SMP Negeri 5 Kendari tahun ajaran 2016/2017 diperoleh nilai sebesar 8,763.

\section{Pembahasan}

Tingkat kesukaran soal tes pilihan ganda maupun soal uraian yang diteliti termasuk kurang baik karena tidak sesuai dengan petunjuk butir soal tes yang baik. Penulisan butir soal yang baik harus memuat $30 \%$ soal yang mudah, $50 \%$ soal yang sedang, dan $20 \%$ soal yang sukar atau dengan perbandingan tingkat kesukaran soal 
untuk tiga kategori mudah, sedang, dan sukar adalah $3: 5: 2$. Pada penelitian ini perbandingan dikatakan baik bila pada tingkat kesukaran soal pilihan ganda dari 20 butir soal sebaiknya terdiri dari 6 butir soal mudah, 10 butir soal sedang dan 4 butir soal sukar atau $6: 10: 4$. Sedangkan pada soal uraian dari 5 butir soal sebaiknya terdiri dari 1 butir soal mudah, 3 butir soal sedang dan 1 butir soal sukar atau $1: 3: 1$. Berdasarkan tingkat kesukaran soal pilihan ganda maupun soal uraian dapat disimpulkan bahwa tingkat kesukaran soal tes sumatif mata pelajaran matematika semester genap kelas VIII SMP Negeri 5 Kendari tahun ajaran 2016/2017 belum dinyatakan baik karena belum memenuhi proporsi yang ditentukan.

Berdasarkan hasil analisis daya pembeda pada soal pilihan ganda terlihat bahwa dari 20 butir soal terdapat 1 butir soal dengan daya pembeda jelek yakni butir soal nomor 20, terdapat 10 butir soal dengan daya pembeda cukup yakni butir soal nomor 1, 3, 4, 5, 7, 8, 9, $10,14,18$, dan terdapat 9 butir soal dengan daya pembeda baik yakni butir soal nomor 2, 6, 11, $12,13,15,16,17$, dan 19. Sedangkan pada soal uraian dari 5 butir soal terdapat 5 butir soal dengan daya pembeda baik yakni butir soal $1,2,3,4$, dan 5 dan terdapat 0 butir soal dengan daya pembeda tidak baik. Dengan demikian dapat disimpulkan bahwa daya pembeda soal pilihan ganda dan soal uraian tes sumatif mata pelajaran matematika semester genap kelas VIII SMP Negeri 5 Kendari tahun ajaran 2016/2017 dinhyatakan berdaya pembeda baik.

Berdasarkan hasil analisis dengan menggunakan program iteman dari 20 butir soal terdapat 17 butir soal $(85 \%)$ memiliki distractor yang berfungsi, yakni butir soal nomor $1,3,5,6,7,8,9,10,11,12,13,14,15,16,17,18$, dan 19 dan 3 butir soal (15\%) memiliki distractor tidak berfungsi yakni butir soal nomor 2, 4, dan 20 . Dengan demikian dapat dikatakan bahwa tes sumatif mata pelajaran matematika semester genap kelas VIII SMP Negeri 5 Kendari tahun ajaran 2016/2017 dinyatakan sudah berfungsi karena dari 20 butir soal terdapat 17 butir soal (85\%) memiliki pengecoh yang berfungsi dan 3 butir soal (15\%) yang pengecohnya tidak berfungsi.

Validitas tes soal pilihan ganda dilihat dengan membandingkan $\mathrm{r}$ hitung dan $\mathrm{r}$ tabel $\left(r_{x y}\right.$ > $r_{t}$ ) maka dari 20 butir soal terdapat 19 butir soal (95\%) yang valid yaitu butir soal $1,2,3,4,5,6,7,8,9,10,11,12,13,14,15,16,17,18$ dan
19 , dan 1 butir soal (5\%) yang tidak valid. Sedangkan pada soal uraian dengan membandingkan $\mathrm{r}$ hitung dan $\mathrm{r}$ tabel $\left(r_{x y}>r_{t}\right)$ dapat dikatakan tes yang valid, karena semua butir soal lebih besar dari $r$ tabel sehingga dapat dikatakan tes yang valid. Dengan demikian dapat disimpulkan bahwa validitas soal pilihan ganda maupun soal uaraian tes sumatif mata pelajaran matematika semester genap kelas VIII SMP Negeri 5 Kendari tahun ajaran 2016/2017 dinyatakan bervaliditas yang baik.

Berdasarkan hasil analisis realibilitas soal pilihan ganda tes sumatif mata pelajaran matematika semester genap kelas VIII SMP Negeri 5 Kendari tahun ajaran 2016/2017 menunjukan bahwa koefisien reabilitas sebesar 0,488 dinyatakan kategori sedang. Sedangkan pada soal uraian diperoleh sebesar 0,713 dinyatakan dalam kategori tinggi. Dengan demikian dapat disimpulkan bahwa reabilitas soal pilihan ganda dan soal uaraian tes sumatif mata pelajaran matematika semester genap kelas VIII SMP Negeri 5 Kendari tahun ajaran 2016/2017 dinyatakan berealibilitas baik.

Berdasarkan hasil analisis pada soal pilihan ganda kesalahan baku pengukuran tes sumatif mata pelajaran matematika semester genap kelas VIII SMP Negeri 5 Kendari tahun ajaran 2016/2017 diperoleh sebesar 1,957. Sedangkan pada soal uraian kesalahan baku pengukuran tes sumatif mata pelajaran matematika semester genap kelas VIII SMP Negeri 5 Kendari tahun ajaran 2016/2017 diperoleh 8,763.

Berdasarkan hasil analisis realibilitas soal pilihan ganda tes sumatif mata pelajaran matematika semester genap kelas VIII SMP Negeri 5 Kendari tahun ajaran 2016/2017 menunjukan bahwa koefisien reabilitas sebesar 0,488 dinyatakan kategori sedang. Sedangkan pada soal uraian diperoleh sebesar 0,713 dinyatakan dalam kategori tinggi. Dengan demikian dapat disimpulkan bahwa reabilitas soal pilihan ganda dan soal uaraian tes sumatif mata pelajaran matematika semester genap kelas VIII SMP Negeri 5 Kendari tahun ajaran 2016/2017 dinyatakan berealibilitas baik.

Berdasarkan hasil analisis pada soal pilihan ganda kesalahan baku pengukuran tes sumatif mata pelajaran matematika semester genap kelas VIII SMP Negeri 5 Kendari tahun ajaran 2016/2017 diperoleh sebesar 1,957. Sedangkan pada soal uraian kesalahan baku pengukuran tes sumatif mata pelajaran 
matematika semester genap kelas VIII SMP Negeri 5 Kendari tahun ajaran 2016/2017 diperoleh 8,763 .

\section{Simpulan dan Saran}

\section{Simpulan}

Berdasarkan hasil analisis dan pembahasan penelitian ini maka dikemukakan beberapa kesimpulan sebagai berikut :

1. Tingkat kesukaran soal pilihan ganda dan soal uraian secara keseluruhan dari 25 butir soal terdapat 3 butir soal (12\%) termasuk kategori mudah, 14 butir soal $(56 \%)$ termasuk kategori sedang, dan terdapat 8 butir soal $(32 \%)$ termasuk kategori sukar. Proporsi tingkat kesukarannya adalah 3:14:8. Sedangkan perbandingan dikatakan baik bila pada tingkat kesukaran soal piihan ganda dan soal uraian dari 25 butir soal sebaiknya terdiri dari 7 butir soal mudah, 13 butir soal sedang, dan 5 butir soal sukar atau 7:13:5. Dengan demikian dapat disimpulkan bahwa tingkat kesukaran tes sumatif mata pelajaran matematika semester genap kelas VIII SMP Negeri 5 Kendari tahun ajaran 2016/2017 belum dinyatakan baik.

2. Daya pembeda soal pilihan ganda dan uraian secara keseluruhan dapat disimpulkan bahwa dari 25 butir soal terdapat 1 butir soal bertanda negatif (4\%), 10 butir soal mempunyai daya pembeda cukup (40\%), 11 butir soal mempunyai daya pembeda baik (44\%), dan 12 butir soal mempunyai daya pembeda baik sekali (48\%). Dapat dikatakan sebanyak $96 \%$ butir soal dinyatakan baik dan $4 \%$ butir soal dinyatakan tidak baik. Dengan demikian dapat disimpulkan bahwa daya pembeda tes sumatif mata pelajaran matematika semester genap kelas VIII SMP Negeri 5 Kendari tahun ajaran 2016/2017 dinyatakan berdaya pembeda baik.

3. Pengecoh (distractor) soal pilihan ganda dari 20 butir soal terdapat 17 butir soal $(85 \%)$ pengecohnya yang berfungsi dan 3 butir soal (15\%) yang pengecohnya tidak beerfungsi. Dengan demikian dapat disimpulkan tes sumatif mata pelajaran matematika semester genap kelas VIII SMP Negeri 5 Kendari tahun ajaran 2016/2017 dinyatakan sudah efektif.

4. Validitas tes sumatif soal pilihan ganda dan uraian secara keseluruhan dari 25 butir soal terdapat 23 butir soal (92\%) yang dikatakan valid dan 2 butir soal (8\%) dikatakan invalid. Dengan demikian dapat disimpulkan bahwa validitas tes sumarif mata pelajaran matematika semester genap kelas VIII SMP Negeri 5 Kendari tahun ajaran 2016/2017 dinyatakan bervaliditas baik.

5. Besarnya indeks reabilitas soal pilihan ganda tes sumatif mata pelajaran matematika semester genap kelas VIII SMP Negeri 5 Kendari tahun ajaran 2016/2017 sebesar 0,515 dinyatakan kategori sedang. Sedangkan reabilitas soal uraian tes sumatif mata pelajaran matematika semester genap kelas VIII SMP Negeri 5 Kendari tahun ajaran 2016/2017 sebesar 0,713 dinyatakan kategori tinggi.

6. Besarnya indeks kesalahan baku pengukuran soal pilihan ganda tes sumatif mata pelajaran matematika semester genap kelas VIII SMP Negeri 5 Kendari tahun ajaran 2016/2017 sebesar 1,957. Sedangkan kesalahan baku pengukuran soal uraian tes sumatif mata pelajaran matematika semester genap kelas VIII SMP Negeri 5 Kendari tahun ajaran 2016/2017 sebesar 8,763. Berdasarkan indikator dari tingkat kesukaran, daya pembeda, pengecoh, validitas, reabilitas tes sumatif mata pelajaran matematika kelas VIII SMP Negeri 5 Kendari Tahun Ajaran 2016/2017 belum berkualitas. Kriteria yang tidak terpenuhi yaitu tingkat kesukaran.

\section{Saran}

Berdasarkan hasil analisis butir soal dan kesimpulan diatas, maka dapat dikemukakan saran sebagai berikut :

1. Tingkat kesukaran soal dalam penelitian ini, secara keseluruhan masih terlgolong sulit. Olehnya itu, perlu diadakan perbaikan agar soal tidak terlalu sulit bagi siswa sehingga soal dapat memenuhi ketentuan proporsi tingkat kesukaran yang ada. Dengan demikian, soal tes sumatif mata pelajaran matematika dapat menunjukan hasil pengukuran yang lebih maksimal dalam mengukur kemampuan siswa.

2. Dalam penelitian ini, ditemukan adanya pengecoh yang tidak berfungsi pada beberapa butir soal. Olehnya itu, perlu diperhatikan lagi distractor pada butir soal yang tidak berfungsi agar dapat berfungsi sehingga soal tes sumatif mata pelajaran matematika dapat menunjukan hasil 
pengukuran yang lebih maksimal dalam mengukur kemampuan siswa.

3. Dalam penelitian ini, masih banyak soal buatan guru yang konteks kalimatnya keliru sehingga membuat siswa dapat kurang memahami maksud dari soal yang diberikan. Oleh karena itu, diharapkan bahwa dalam pembuatan soal terutama pada tes sumatif harus lebih diperhatikan kualitas tesnya khususnya pada kalimat soal dan yang terpenting lagi pada pilihan jawaban.

\section{Daftar Pustaka}

Aliati. 2013. Kualitas Tes Ujian Nasional Matematika Siswa SMP Negeri di Kabupaten Buton Utara Tahun Ajaran 2011/2012. Kendari: Skripsi FKIP UHO:.

Aliati dan Ibrahim Muchtar. 2013. Kualitas Tes Ujian Nasional Matematika Siswa SMP Negeri di Kabupaten Buton Utara Tahun Ajaran 2011/2012. Jurnal Penelitian Pendidikan Matematika Volume 1, No. 1.

Arifin, Zaenal. 2009. Evaluasi Pembelajaran Prinsip Teknik Prosedur. Bumi Siliwangi: Rosda.

Arikunto, Suharsimi. 2016. Dasar-Dasar Evaluasi Pendidikan Edisi 2. Jakarta: Bumi Aksara.

Arikunto, Suharsimi. (2016). Dasar-Dasar Evaluasi Pendidikan Edisi 2. Jakarta: Bumi Aksara.

Daryanto. (2001). Evaluasi Pendidikan. Jakarta: Rineka Cipta.

Erlina, A. (2012). Analisis Soal Ulangan Akhir Semester 1 Kelas X SMA Negeri Banyumas Mata Pelajaran Matematika Tahun Pelajaran 2011/2012. Semarang: Skripsi FKIP Institut Agama Islam Negeri Walisongo.

Djanuarsih, Eri. 2016. Validitas dan Reliabilitas Butir Soal. http://www. Freewebs.com/santyasa/PDF_Files/ANA LISIS_BUTIR.pdf.

Erlina, A. 2012. Analisis Soal Ulangan Akhir Semester 1 Kelas X SMA Negeri Banyumas Mata Pelajaran Matematika Tahun Pelajaran 2011/2012. Semarang:
Skripsi FKIP Institut Agama Islam Negeri Walisongo.

Jihad, Asep dan Haris, Abdul. 2012. Evaluasi Pembelajaran. Yogyakarta. Multi Prosindo.

Liliasari. 2015. Validitas dan Reabilitas Instrument Tes Matematika Dasar yang Berkaitan dengan Pendahuluan Fisika Inti. Jurnal Inovasi dan Pembelajaran Fisika, Volume 2, Nomor 1.

Sanjaya, Wina. 2008. Perencanaan dan Desain Sistem Pembelajaran. Bandung: Remaja Rosdakarya.

Sudjana, Nana. 2006. Penilaian Hasil Belajar Proses Belajar Mengajar. Bandung: PT. Remaja Rosdakarya.

Sudijono, Anas. 2015. Pengantar Evaluasi Pendidikan. Jakarta: Rajawali Pers.

Suryabrata. 2000. Pengembangan Alat Ukur Psikologis. Yogyakarta: Andi.

Suryawati \& Yulfikar. 2012. Kualitas Tes Hasil Belajar Matematika Siswa Kelas VIII SMP Negeri 9 Banda Aceh Tahun Pelajaran 2012/2013. Jurnal Peluang, Volume 1, No. 1.

Hendriana, Heris \& Soemarno, Utari. (2014). Penilaian Pembelajaran Matematika. Bandung: PT Refika Aditama.

Jihad, Asep \& Abdul Haris. (2012). Evaluasi Pembelajaran. Yogyakarta: Multi Presindo.

Liliasari, Cicylia T. Kereh, Paulus C. Tjiang, dan Jozua Sabandar. (2015). Validitas dan Reliabilitas Instrumen Tes Matematika Dasar yang Berkaitan dengan Pendahuluan Fisika Inti. Jurnal Inovasi Dan Pembelajaran Fisika, Vol. 2, No. 1, Hal. 36-46.

Sitti Fatimah. (2014). Kualitas Tes Sumatif Mata Pelajaran Matematika Kelas VIII Semester Genap SMP Negeri 2 Sawa Tahun Pelajaran 2012/2013. Kendari: Skripsi FKIP UHO tidak Dipublikasikan. 
Jurnal Penelitian Pendidikan Matematika Volume 6 No. 3 September 2018

Sudijono, Anas. (2015). Pengantar Evaluasi Pendidikan. Jakarta: Rajawali Pers.

Sukardi. (2015). Evaluasi Pendidikan: Prinsip dan Operasional. Jakarta: Bumi Aksara.

Yusuf, Muri. (2015). Asesmen dan Evaluasi Pendidikan. Jakarta: Kencana. 